\title{
Stakeholder Influence in Institutional Strategic Planning Practices in Public Secondary Schools in Kenya (A Survey of Public Secondary Schools in Migori County)
}

\author{
Julia Ashibambo Weyama \\ Faculty of Commerce, Department of Business and Management, Kisii University, Kisii, Kenya
}

Email address:

julieweyama@gmail.com

\section{To cite this article:}

Julia Ashibambo Weyama. Stakeholder Influence in Institutional Strategic Planning Practices in Public Secondary Schools in Kenya (A Survey of Public Secondary Schools in Migori County). International Journal of Economic Behavior and Organization.

Vol. 6, No. 1, 2018, pp. 22-28. doi: 10.11648/j.ijebo.20180601.13

Received: December 14, 2017; Accepted: January 5, 2018; Published: June 6, 2018

\begin{abstract}
This paper tries to explore the influence of stakeholders in institutional strategic planning practices in public secondary schools in Kenya, a case of Migori County. The study employed a descriptive survey study. The target population was made up of public secondary school head teachers, deputy head teachers and heads of departments in secondary schools within Migori County whose total was 1056. A sample size of 106 respondents was drawn using stratified random sampling. The study used both primary and secondary data. Questionnaire was the primary data collection tool and was administered using the drop and pick method which helped minimize financial and time limitations that the researcher was likely to face. Secondary data was derived from documentations such as school strategic plans and minutes of B.O.G, P.T.A and staff meetings. Data collected was both qualitative and quantitative. Qualitative data was analysed using content analysis while quantitative data was analysed using descriptive statistics such as mean, mode and median. The results of the study indicated that strategic planning process in public secondary schools involves stakeholders to a minimal extent mostly because of the time that it would involve.
\end{abstract}

Keywords: Strategic Planning, Strategy Formulation, Stakeholders, Public Secondary Schools, Competition

\section{Introduction}

\subsection{Background Information}

This study was motivated by the importance of strategic planning in organizations and the significance of the education sector in Kenya towards achieving the vision 2030 and the millennium development goals.

Management involves the use of organizational resources to achieve organizational objectives. The organizational resources within the disposal of the manager include; Human, financial, physical and information resources. The manipulation of these resources to meet organizational objectives requires employment of various management tools, an important one being the strategic planning.

Strategic planning is a process that entails a detailed analysis of both the external (to identify opportunities and threats) and internal environments (to identify the organizational strengths and weaknesses), strategy formulation which involves selection of strategies that build on the organization's strengths and correct its weaknesses in order to take advantage of external opportunities and counter external threats, implementation of the strategies and continuous monitoring and evaluation of the entire process at every stage [12].

\subsection{Strategic Planning in Kenya}

In Kenya Strategic planning was introduced in the public sector through the structural adjustment programmes that were introduced in the 1980's although progress made has been different in various sectors, much determination has yielded some significant benefits.

Kenya's vision 2030 is the country's new development blueprint covering the period 2008 to 2030 and it aims to transform Kenya into newly industrializing country. The vision is based on three pillars namely; economic, social and 
political. The Social Pillar in the Vision 2030 singles out education and training as the vehicle that will drive Kenya into becoming a middle-income economy. In addition, the Constitution, 2010 has provided for Free and Compulsory Basic Education as a human right to every Kenyan child. The country is therefore obliged to align education and training to the demands of the two documents [20].

In addition Other challenges facing public secondary schools include; ineffective school management, lack of teacher motivation, inadequate funding, poor school management practices, mismanagement of school funds, eneffective inspection of schools among others [41]. These challenges could be overcome through comprehensive planning ranging from the ministry headquarters to specific institutions.

Migori county public schools are faced with a number of challenges that could be alleviated by careful strategic planning. Some of these challenges as obtained from the county director of education include; poverty, low enrolment, low transition rate, gender inequality, poor infrastructure, high dropout rate and lack of facilities among others.

\subsection{Statement of the Problem}

Recent research studies have made it clear that there is an increased internal and external uncertainty in organizations due to emerging opportunities and threats together with lack of the awareness of the exact organizational needs. This can come inform of changes in technological, social, political and economic forces. As a result of these changing forces, the management process at all levels in both private and public sector has become more difficult, requiring greater skills aimed at driving the future course of the organizations in the midst of uncertain world. Strategic planning comes in handy in providing these skills [44]. Other studies reveal a significant relationship between strategic planning and organization's performance. A study carried out in Turkey's companies revealed that strategic planning leads to improved financial performance of the organization [1]. Other factors affecting strategic plan implementation according to research carried out in government tertiary institutions in Kenya include; weak influence of managerial behavior, poor incentives and rewards systems which demoralizes the staff who are key stakeholders [38]. Dr Kiprop and Dr Kanyiri in their study on challenges facing the adoption of strategic planning in secondary schools in Kirinyaga district recommended a comprehensive training for headteachers, harmonization of existing policies, involvement of all stakeholders and school management seeking collaboration with other stakeholders such as NGO's and civil societies [19].

Available data from the county education office indicate that most secondary schools in Migori County have been reluctant in the formulation and implementation of strategic plans. The far that most of them can go is the formulation stage, leaving out the most important stages of implementation and continuous evaluation. This is because the ministry has made it mandatory for all schools to have in place a strategic plan. Furthermore the formulation for most schools rarely involves a thorough analysis of the external and internal environment to come up with workable strategies because of the time limit. If this continues, the government may not realize its policy on decentralization of management to institutions and the success of many schools is hindered.

It is for this reason that this study sought to find out the stakeholder influence in institutional strategic planning practices in public secondary schools in Migori County.

\subsection{Objective of the Study}

The general objective of this study was to investigate the stakeholder influence in institutional strategic planning practices in public secondary schools in Migori County.

\section{Literature Review}

\subsection{Theories of Strategic Planning}

For the purposes of this study, three theories on strategic planning were reviewed to form its conceptual basis. They include the five forces competition theory, the 3Cs theory (corporation/company, customer and the competitor) and the theory of environmental turbulence as explained in the proceeding sub-section.

\subsubsection{Five Forces Competition Theory}

The theory was developed by a management theorist Michael porter and forms a major basis for strategic planning. These forces allows an organization to identify potential environmental influences that shape the competitive context in which it must operate. According to porter, the essence of strategy formulation is coping with competition and the state of competition in any industry depends on five basic forces namely; Rivalry, Threat of Substitutes, Buyer Power, Supplier Power, and Barriers to Entry/Threat of Entry. His position is that the collective strength of these forces determines the ultimate profit potential of an industry. If the forces are intense, almost no company earns attractive returns on investment. If the forces are mild, many companies are profitable. The manager's goal according to Porter is to find a position in an industry where he/her company can defend itself against these forces or can influence them in its favour. Understanding the competitive forces, and their underlying causes, reveals the roots of an industry's current profitability while providing a framework for anticipating and influencing competition (and profitability) over time. The strongest competitive force or forces determine the profitability of an industry and become the most important to strategy formulation [31].

\subsubsection{Kenichi Ohmae's 3Cs Theory}

Dr Kenichi Ohmae, a management guru from Japan, developed the $3 \mathrm{Cs}$ model. This model shows that a strategist should focus on three key factors for success namely; the 
corporation/company, customer and the competitor. According to Kenichi Ohmae the sole purpose of strategic planning is to gain a competitive advantage over competitors in the industry. Strategic planning's purpose is to enable a company to gain, as efficiently as possible, a sustainable edge over competitors [37].

\subsubsection{The Theory of Environmental Turbulence}

The theory was developed by Igor Ansoff in the 1960's. Igor Ansoff is said to be the father of strategic management. His book on corporate strategy provided guidance on how to plan for the future. The system of planning by then paid very little attention to strategic issues. With the advent of greater competition, higher interest in acquisitions, mergers and greater turbulence in the business environment, strategic issues could not be ignored. According to Ansoff, effective response to the environment is the key to long run strategic success. The environment in this case is the economic, political, sociological, psychological, technological and geographical forces in the segment of the world in which the business chooses to operate. Ansoff felt that in developing strategy, it was important for an organization to anticipate future environmental challenges and draw up appropriate strategic plans for responding to these challenges. According to his theory, to be effective, a company's strategy needs to match the level of turbulence present in its environment. Ansoff recognized five levels of environmental turbulence in which an organization can operate namely; stable, expanding, changing, discontinuous and surprising.

\subsection{Stakeholder Influence in Institutional Strategic Planning Practices in Public Secondary Schools in Kenya}

An organization's stakeholders are individuals or groups with interest, claims, or stakes in the organization, in what it does and in how it performs. They can be categorized into internal such as employees, managers, Board members and stockholders, and external stakeholders such as government, local community, creditors, suppliers, unions and creditors [12]. Every group of stakeholders have interests that they need to be considered in running of the organization to an extend that sometimes the goals of different groups may conflict. Hill and Jones advices that it is important to perform a stakeholder impact analysis that enables an organization to identify the most important stakeholders and give highest priorities to pursuing strategies that satisfy their needs [12].

The stakeholders in a school include teachers, students, local community, Board of governors, the ministry of education, the government, suppliers, the parents and nonteaching staff within the school. Stakeholders' interests are not always consistent and the various stakeholders are not always affected in the same way by every strategic decision. Their influence will therefore vary from one decision to decision. This will determine which stakeholders will be given priority in any strategic decisions. Stakeholders should be in a position to determine the content and implementation of any strategic plan but the major decision makers in an institution should be in a position to identify the key stakeholders to be involved in the strategic planning process [8]. Bryson [12] asserts that an organization's survival and prosperity depends on the extent to which it satisfies its key stakeholders and an organization's strategy will be successful only if it meets the needs of key stakeholders hence the need to involve them in the entire strategic planning process (ibid).

A study carried out in South Africa on participatory decision making in schools revealed some factors that hindered stakeholder participation in the management of schools. These factors include; lack of skills and poor understanding of some school issues, time pressure resulting from other commitments, some teachers negative attitudes toward them, low education or lack of it among some especially parents. The students on the other hand as important stakeholders were denied the opportunity to participate in school wide decision making structures by adult governors perceived gap between professional knowledge (teachers and principals) and lay knowledge (learners), deeply rooted cultural expectations of adult governors towards learners and adult perceiving learners as minors who lack experience to contribute constructively in the debate [45]. Stakeholder involvement in the strategy implementation results in a broader support in the implementation of organizational strategies and collaborative problem solving during the implementation phase.

\subsection{Summary of Gaps to Be Filled by the Study}

A review of literature on the challenges facing the development of strategic planning practices in public secondary schools reveals that much of the training has focused on school principals, leaving out the other important stakeholders involved in the day to day running of the schools. This research focused on a holistic training with a view that organizations are open systems and any effect on one part of the systems affects the whole.

Studies have revealed the importance of stakeholders in strategic planning practices in any organization but they are silent on how specifically the interests of stakeholders can affect the development of strategic planning practices

\section{Research Methodology}

\subsection{Research Design}

A descriptive research design was applied for the purpose of accessing the intent of the study. The major purpose of the design is a description of the state of affairs as it exists at present [29]. Descriptive studies result in the formulation of important principles of knowledge and solution to significant problems [33].

\subsection{Target Population}

The study's target population was the school principals, deputy principals and head of departments in the public secondary schools in Migori County. This composition translates to a total number of 1056 given that there are a 
total of 176 public secondary schools in Migori County. Each of the schools has one principle, one deputy principle and a minimum of four heads of departments making a total of six respondents in every school.

\subsection{Sample Size and Sampling Design}

The study used stratified random sampling method to select a sample of 106 informants at 0.10 sampling ratio. Dawson [16] asserts that the size of the sample depends upon the type and purpose of research. Table 1 . below shows the sample size.

Table 1. Sample size.

\begin{tabular}{llll}
\hline SUB-COUNTY & Target population & \% & Sample size \\
\hline Rongo & 192 & 18 & 19 \\
Uriri & 108 & 10 & 11 \\
Awendo & 96 & 09 & 10 \\
Migori & 234 & 22 & 23 \\
Nyatike & 210 & 20 & 21 \\
Kuria East & 90 & 09 & 09 \\
Kuria West & 126 & 12 & 13 \\
TOTAL & 1056 & 100 & 106 \\
\hline
\end{tabular}

Source: Researcher (2013).

\subsection{Data Collection Instruments}

The study used both secondary and primary data. Secondary data basically reviewed relevant documentations such as the strategic plans, minutes of B.O.G, P.T.A and staff meetings. On the other hand, primary data concentrated on respondents' opinions and appraisals concerning the study variables. To assist the researcher gather the primary portion of data, the study adopted a questionnaire instrument which was self-administered. Most importantly, the instrument's structure was designed to accommodate all the influence of stakeholders on the strategic planning practices in public secondary schools.

The questionnaires were distributed using drop and pick method and telephone calls were made to enhance quick response.

\subsection{Instrument Validity and Reliability}

The study adopted pre-testing as one comprehensive procedure towards enhancing instrument validity and reliability. The pilot units, equivalent to one-tenth of the proposed sample size, were obtained from comparable members of the population from which the sample for the full study was taken. This size is informed by Mugenda [33] who regard the proportion as sufficient for pilot testing.

The results from the pilot testing were used to fine-tune and finalize the questionnaire. The pilot participants were not involved in the ultimate field study.

\subsection{Data Analysis}

The collected data were thoroughly examined and processed prior to drawing inferences through a series of operations involving editing to eliminate inconsistencies, classification on the basis of similarity and tabulation to relate variables. Subsequently, the refined and organized data was coded and analysed using descriptive statistics involving percentages to determine varying degrees of responseconcentration. An advantage of descriptive statistics is that they make a mass of research material easier to read by reducing a large set of data into a few statistics or some picture such as graph or table [4]. Descriptive statistics was invaluable in describing the sample data in such a way as to portray the typical respondent and to reveal the general pattern of responses.

The statistics were generated with aid of the computer software, Statistical Package for Social Sciences (SPSS) Version 20.0. Further, the researcher ensured that resulting summaries from the findings presented data in a consolidated and meaningful framework, and thus, the analysis focused on accuracy and reliability in relation to the study's pre-designed objectives. Finally, for the purpose of communicative effectiveness to ultimate users, findings were presented using both tabular and graphical representations.

\section{Data Analysis and Presentation of Findings}

\subsection{Response Rate}

The study had set to obtain intended feedbacks from a total of 106 participants working in various management positions in public secondary schools as either school principals, deputy principles or heads of various departments. Despite the fact that all target respondents were approached for responses, three did not return the questionnaires sent to them. This resulted to an aggregate of 103 successful completions, representing a response rate of $97 \%$.

\subsection{Effect of Stakeholder Interest on Development of Strategic Planning Practices}

The study therefore sought to investigate the extent to which the respondents thought stakeholders in their institutions were involved in strategic planning practices through decision making.

From the findings, a higher percentage of respondents thought that stakeholders were involved to a small extent in decision making (68.87\%). Only $12.26 \%$ agreed that stakeholders were involved to a very great extent and $9.43 \%$ thought the stakeholders were not totally involved in major decision making within the institutions. The frequency table below shows the complete percentages of responses received. 
Table 2. Stakeholder involvement in strategic planning practices in public sec schools.

\begin{tabular}{llllll}
\hline \multicolumn{1}{l}{ Stakeholders involvement in strategic planning } & & & & Cumulative Percent \\
\hline \multirow{4}{*}{ Valid } & Frequency & Percent & Valid Percent & 12.3 \\
& To a very great extend & 12 & 12.1 & 12.3 & 19.8 \\
& To a great extend & 8 & 7.5 & 7.5 & 88.7 \\
& To a small extend & 72 & 68.2 & 68.9 & 98.1 \\
& Not at all & 19 & 9.3 & 9.4 & 100.0 \\
& Not sure & 2 & 1.9 & 1.9 & \\
\hline
\end{tabular}

Source: Research Data (2013).

\subsection{Content Analysis}

The researcher used content analysis technique to analyse qualitative data. All the schools under study had a school mission and vision and a tangible strategic plan. A review of minutes of B.O.G revealed in 15 schools that the strategic plan was discussed with the B.O.G before the final plan. About five schools involved both the B.O.G and the P.T.A members in the formulation process. Most that could not involve the various stakeholders complained of the time limit bearing in mind that they had other businesses to attend to including teaching. Motivation of staff and students was evident in all the schools that participated because all of them hold annual A.G.M's where they acknowledge the best staff and students in the various areas. All the schools that participated had no specific plans for staff training complaining of limited resources but about 12 schools agreed that they organize for frequent discussion sessions between staff and students. This sharing of ideas plays a great role in strategic planning process. Most of the respondents thought that the major hindrances to strategic planning practices are resources and time. To most of the respondents, strategic planning is an important management activity that can lead to the success of the schools in various areas.

\section{Conclusion and Recommendations}

\subsection{Conclusions}

The study findings make the researcher to conclude that stakeholders are not fully involved in strategic planning practices. Most important stakeholders such as teachers, students, and non-teaching staff and community spokespersons are rarely involved in making major decisions that affects their interests and that of the school.

\subsection{Recommendations}

All stakeholders ought to be involved in strategic planning practices in the secondary schools. Although not all parents in public secondary schools are literate, it is important to incorporate their representative's ideas when formulating the strategic plan and also at the implementation stage. Furthermore parents may be required to offer financial support for implementation of some of those strategies. Students ought to be involved especially in those decisions that would affect their day to day existence in their school environment. Their involvement would reduce any resistance to change and would also bridge the gap that normally exists between the school administration and the students. Lack of teacher involvement in the strategic planning process likewise leads to resistance to change.

The success of the Strategic planning in public secondary schools like any other organization ought to be holistic in nature incorporating every aspect of the institution. The proper functioning of the school like a system depends on how much the different stakeholders are involved, excluding any one of them interferes with the normal functioning. The major stakeholders should therefore be involved from the formulation stage right to the implementation and continuous control while other stakeholders should be made aware of major decisions that affect their daily operations in the institutions.

\section{References}

[1] Alev M Efendioghu. (2010). Strategic planning in organizations. Reseach journal of business and management, school of business and proffessional studies, vol 3442 (No55), 2.

[2] Algozzine, H. D. (2006). Doing case study reseach: A Practical guide for beginning reseachers. Columbia: Colombia university.

[3] Ansoff, H. (1990). Implanting strategic management (2nd edition ed.). New york: Prentice-Hall.

[4] Argyrous, G. (2005). Statistics for research with a guide for SPSS. New york: Sage publications.

[5] Baloyi, A. \&. (2010, june 29th). Factors affecting the implementation of the corporate strategy of the Mpumalanga Department of education: Analytical approach. Unpublished research. Retrieved May 20th, 2013, from University of limpopo: http://hdl.handle.net.

[6] Bank, W. (2006). Kenya Education sector programme (KESSP). Project appraissal document. Washington D. C: World Bank.

[7] Black, R. J. (2003). Organizational culture: Creating the influence needed for strategic success. UK: ISBN.

[8] Bryson, J. (2004). Strategic planning for public and non-profit organization. San Francisco: Jossey-Bass.

[9] Buluma P. I, D. M. (2013, February 10th). Human resource related factors affecting the implementation of strategic plans in local authorities in kenya: A case of Municipal council of Eldoret. Retrieved April 20th, 2013, from European Journal of Business and Management. Vol 5, No 3.: http://www.iiste.org. 
[10] Buluma, I. \&. (2013). Institutional related factors affecting the implementation of strategic plans in local authoritites in kenya: A case of municipal council of Eldoret. International journal of business and management., vol 8 (No 10), 8-9.

[11] Cameron, K. \&. (1999). Diagnosing and changing organizational culture: Based on competing values framework. New york: Addition Wesley.

[12] Charles W. L, H. \&. (2008). Strategic management theory: An intergrated approach (9th edition ed.). South-western: Cengage learning.

[13] Cheruiyot Daniel, K. (2006, August 10th). Trainning needs for pulic secondary school head teachers in Nandi south district, kenya. Unpublished reseach. Retrieved may 12th, 2013, from Nairobi university: http://erepository.uonbi.ac.ke.

[14] Colelough, W. O. (2006). Financing education in kenya: Expenditures, outcomes and roles of international Aid. Nairobi: Kenyatta university, department of education foundation.

[15] Cook.W. J. (1995). Strategic planning in the American schools (2nd edition ed.). Cambrige: Arlington cambrigde.

[16] Dawson, D. C. (2002). Practical reseach methods: A user friendly guide to mastering reseach techniques and project. United kingdom: Oxford ox41RE.

[17] Deal, T. (2005). Cultural change: Opportunity, Silent killer or metamorphosis (2nd edition ed.). Sanfrancisco: Jossey-Bass.

[18] Ded, T. (2008). Pedagogical challenges to planning and education in UK and Europe. UK: Newcastle university.

[19] Dr Catherine Jematai Kiprop and Dr Joyce Kanyiri. Challenges In The Adoption of Strategic Planning in Public Secondary Schools in Kenya: A Case of Kirinyaga Central District. Retrieved may 20th, 2013, from https://www.researchgate.net/publication.

[20] education, M. o. (February 2012). Towards a globally competitive quality education for sustainable development: Re-alighning kenya's education to the constitution 2010 and vision 2030. Nairobi: Repulic of kenya, ministry of education.

[21] Gathoni, J. (2013, February 26th). Factors influnecing Implementation of strategic plans: A case of department of veterinary services in kenya. Unpublished research. Retrieved may 20th, 2013, from Nairobi university: http://erepository.uonbi.ac.ke.

[22] Government of kenya, M. o. (2005). A policy framework for education, Trainning and research. Nairobi: Government of kenya printers.

[23] Hussey, D. (1998). Strategic management: From theory to implementation. Butterworth: Butterworth-Heinemann.

[24] Ibrahim, N. (2011). Preparation and development of public secondary schools principals in kenya. International journalof humanities and social sciences, 1 (9), 5.

[25] J. A., P. \&. (2000). Formulation, Implementation and control of competititve strategy. New york: Irwin mc Graw-Hill.

[26] kanyingi, D. C. (2012). Challenges in the adoption of strategic planning in public secondary schools in kenya: A case of kirinyaga district. International journal of scientific research, vol 6 (No 2277), 7.
[27] Keith, M. (2008). Strategies for sustainable financing of secondary education in sub saharan Africa. World bank working paper No 136, 4-8.

[28] kenya, G. o. (2012). A policy framework for education: Alighning education and trainning to the costitution of kenya 2010 and kenya vision 2030 and beyond. Nairobi: Gok printers.

[29] Kothari. (2003). Reseach methodology. New Delhi: New age international Ltd.

[30] Macharia, L. (2013, january 21). Strakeholder involvement in the success of strategy implementation among public secondary schools in Nairobi, kenya. Unpublished reseach. Retrieved may 20th, 2013, from Nairobi university: http://erepository.uonbi.ac.ke.

[31] Michael, E. (2008). The five competititve forces that shape strategy. Harvard business review, http://www.hbr.org, 2-3.

[32] Ministry of education, s. a. (2004). A policy framework for education, Training and reseach: Meeting challenges of education, training and reseach in kenya in the 21st century. Nairobi: Gok printers.

[33] Mugenda, M. A. (2003). Reseach methods: Quantitative and qualitative approaches. Nairobi: Acts presss.

[34] Muya, J. a. (2012). The impact of organizational culture on performance of educational institutions. International journal of business and social science.http://www.ijbssnet.com, 3 (8), 14.

[35] Ndungo, P. N. (2013). Factors affecting formulation of strategic plans in private primary schools: A case of schools in Githunguri district. Unpublished research. Kenyatta university, p. 1.

[36] Ogembo, P. (2005, november 16). Training needs of heads of departments of secondary schools for effective curriculum implementation in kenya: A case of Eldoret municipality. Unpublished Mphil Thesis. Retrieved may 18, 2013, from Nairobi university: http://erepository.uonbi.ac.ke.

[37] Ohmae, K. (1982). The mind of a strategist. Mc GrawHill.http://www.ohmae.ac.jp.gmba/faculty/ohmae.html.

[38] olujunke, A. s. (2007). Impact of strategic planning on organizational performance and survival. Reseach journal of business management vol 10 No 20, 2-3.

[39] Omboi, B. \&. (2010). Factors affecting the implementation of strategic plans in government Tertiary institutions: A survey of selected Technical training institutes. European journal of business and management, 3 (3), 98-99.

[40] Onyango, G. (2006). Competencies needed by secondary school head teachers and implications for pre-service and in service education: A case of Nairobi and Kakamega districts (kenya). Unpublished research. Kenyatta university.

[41] Oyugi, L. (2011, april 6th). Factors affecting implementation of government community strategy by community units in Bondo District of kenya. Unpublished research. Retrieved may 25th, 2013, from Nairobi university: http://erepository.uonbi.ac.ke.

[42] Prof Mwenje, R. (2008). Radical reforms for kenyas' education sector: Implementing policies responsive to vision 2030. Institute of policy Analysis and research.http://www.ipar.orke, 4. 
[43] Saitoti, G. (2003). Education sector review: How far have we come since independence and what still needs to be done to meet the education needs of all kenyans, kenya (2010) and vision 2030 and beyond. Nairobi: Gok printers.

[44] Singh, M. (2008). Strategic management and competititve advantage. New Delhi: Global India publications.

[45] Steiss, A. W. (2003). Strategic management for public and nonprofit organizations. Virginia, USA: Virginia polytechnic institute and state, university Blacksburg.

[46] Val Candy, J. G. (2011). The historic development of strategic planning Theories. International journal of management and information systems, 15 (4), 74.
[47] Wangatho, J. (2007, sept 41). Stakeholder perception of effectiveness in BOG management of public secondary schools in Nyandarua district. Retrieved may 21, 2013, from Nairobi university: http://erepository.uonbi.ac.ke.

[48] World Bank A. H, D. (2007). Secondary education in Africa: At the crossroads; Choices for secondary education and trainning in Sub Saharan Africa. Wasington D. C: World Bank. 